\title{
In vitro transport of $\beta$-lactoglobulin across the jejunum of lactose-fed rats
}

\author{
JF Huneau *, D Tomé \\ INRA, Laboratoire de Nutrition Humaine et Physiologie Intestinale, \\ et INSERM U290, Hôpital St-Lazare, 75010 Paris, France
}

(Received 19 September 1989; accepted 12 January 1990)

\begin{abstract}
Summary - Changes in protein absorption through the intestinal mucosa occur with aging and might reflect modifications in enterocyte membrane characteristics. We have observed that bovine $\beta$-lactoglobulin ( $\beta-L G$ ) was efficiently transported across the small intestine of adult rats in vitro and that $12-16 \%$ of the absorbed protein was recovered intact or as large hydrophobic peptides. Ten percent lactose-feeding resulted in decreased tissue conductance and significantly reduced $(-58 \%$, $P<0.05) \beta-L G$ transport across rat small intestinal mucosa. The amounts of $\beta-L G$ absorbed, either as amino acids and peptides or as intact protein, were reduced to the same extent. Therefore, the effect of lactose feeding might be related to a decrease in protein endocytosis at the brush-border level, rather than to reduced protein transport across tight junctions.
\end{abstract}

intestine / $\beta$-lactoglobulin / lactose / transport / rat

Résumé - Transport in vitro de $\beta$-lactoglobuline à travers le jéjunum de rats nourris au lactose. L'absorption intestinale des protéines varie en fonction de l'âge des animaux, peut être en raison de modifications affectant les caractéristiques membranaires des entérocytes. Nous avons observé que la $\beta$-lactoglobuline bovine ( $\beta$-LG) est absorbée efficacement par le jéjunum de rat adulte. Douze à quinze pour cent de la protéine absorbée in vitro sont retrouvés intacts ou sous forme de gros peptides hydrophobes. L'introduction de $10 \%$ de lactose dans l'alimentation provoque une diminution de la conductance tissulaire et réduit de façon significative $(-58 \%, \mathrm{P}<0,05)$ le transport de la $\beta$-LG. Cette réduction affecte de façon similaire les composantes intacte et dégradée du transport de cette protéine. L'effet du lactose pourrait être lié à une réduction de la captation des protéines par endocytose au niveau de la bordure en brosse des entérocytes plutôt qu'à une diminution d'un éventuel transport paracellulaire des protéines.

intestin / B-lactoglobuline / lactose / transport / rat

\footnotetext{
* Correspondence and reprints
} 


\section{INTRODUCTION}

Bovine milk represents an important source of dietary proteins for humans. In bovine milk, $\beta$-lactoglobulin ( $\beta$-LG) represents the major whey protein, with a concentration of up to $3.7 \mathrm{~g} / \mathrm{l}$. $\beta$-LG is considered to be responsible for allergic reactions to milk (Fällström et al, 1978; Huang et al, 1985), and is also suspected to play a role in the transport of ligands through the intestinal epithelium (Papiz et al, 1986; Said et al, 1989).

$\beta$-LG has been demonstrated to be especially resistant to digestion in vitro and in vivo (Miranda and Pelissier, 1983; Koritz et al, 1987; Reddy et al, 1988). In vitro experiments have led to the conclusion that an uptake of intact $\beta$-LG occurs in adult small intestine (Stern and Walker, 1984; Marcon-Genty et al, 1989). Up to 0.43 $\mu \mathrm{g} \cdot \mathrm{h}^{-1} \cdot \mathrm{cm}^{-2}$ antigenic $\beta-L G$ crossed rabbit ileum mounted in the Ussing chamber (Marcon-Genty et al, 1989), and using isolated ileal loop in situ, up to $2.03 \mathrm{ng} \cdot \mathrm{ml}^{-1}$ of antigenic $\beta$-LG was recovered in the portal blood per $\mathrm{cm}^{2}$ of ileal mucosa (Gotteland et al, 1989).

Both histologic (Cornell et al, 1971; Walker et al, 1972) and metabolic (Heyman et al, 1982; Marcon-Genty et al, 1989) evidence has shown that protein transport across the epithelium is mainly transcellular and proceeds by endocytosis, intracellular transport and exocytosis through the basolateral membrane. Therefore, it has been suggested that modifications in enterocyte membrane composition may affect protein absorption by the gut (Udall and Walker, 1982).

Intestinal epithelium renewal and maturation is affected by many factors such as hormones (Johnson, 1976), microflora (Abrams et al, 1963; Meslin et al, 1974) and food (Ecknauer et al, 1981). Lactose, a disacharide which is known to bypass hydrolysis in adult rat small intestine, may induce changes in intestinal epithelium maturation since $10 \%$ lactose feeding has been shown to provoke a significant increase in the epithelium renewal time of the conventional adult rat ileum (Meslin et al, 1981).

The aim of the present study was to investigate the effect of lactose-feeding on intestinal protein absorption by the adult rat intestine. For that purpose, the jejunums of lactose-fed and control rats were mounted in Ussing chambers in order to investigate transepithelial transmission of $\beta$ lactoglobulin.

\section{MATERIALS AND METHODS}

\section{Chemicals}

$\left[{ }^{14} \mathrm{C}\right]$-formaldehyde $(0.74 \mathrm{GBq} / \mathrm{mmol})$ was purchased from Amersham (Les Ulis, France) and bovine $\beta$-LG was obtained from Sigma (La Verpillière, France). Radiolabeling of $\beta-L G$ with ${ }^{14} \mathrm{C}$ was achieved by reductive alkylation of lysine amino groups using $\left[{ }^{14} \mathrm{C}\right]$-formaldehyde, as previously described (Jentoft and Dearborn, 1979). Labeled $\beta$-LG had a specific activity of $3.910^{6}$ $\mathrm{cpm} / \mathrm{mg}$.

\section{Animals and diets}

Ten male conventional Fisher F344 rats were housed with a constant temperature and lighting cycle, and fed lactose-free commercial pellets (UAR ref 0340, Epinay/Orge, France) from weaning until the age of 9 wks. They were then randomly divided into 2 groups and received for a 4 wk feeding period, either a semi-synthetic (control) diet $(57.5 \%$ corn starch, $20.5 \%$ casein, $9 \%$ corn oil, $5 \%$ cellulose, $5 \%$ minerals, $8 \%$ vitamin mixture), or the same semi-synthetic diet, in which $10 \%$ lactose was substituted for an equiv- 
alent amount of starch. The animals had free access to water and food. Daily weight gains were similar with both diets $(4.1$ and $4.0 \mathrm{~g} / \mathrm{d}$, for control and lactose diets, respectively).

\section{Ussing chamber experiment}

At the end of the feeding period, rats were fasted overnight and anesthetized with an ip injection of sodium pentobarbital $(5 \mathrm{mg} / 100 \mathrm{~g}$ body weight). The jejunum (beginning $10 \mathrm{~cm}$ distal to the Treitz ligament) was removed, rinsed with cold saline, and mounted in the Ussing chamber, as previously described ( $\mathrm{Li}$ et al, 1989). Both faces of the tissue (exposed area, $0.5 \mathrm{~cm}^{2}$ ) were bathed with $10 \mathrm{ml}$ of bicarbonate Ringer containing (in $\mathrm{mM}$ ): $\mathrm{Na}^{+} 140, \mathrm{Cl}^{-120}, \mathrm{~K}^{+} 5.2$, $\mathrm{Ca}^{2+1} .2, \mathrm{Mg}^{2+1} .2, \mathrm{HCO}_{3}-25, \mathrm{HPO}_{4}^{2-} 2.4$ and $\mathrm{H}_{2} \mathrm{PO}_{4}^{-} 0.4$, pH 7.4, and gassed with $\mathrm{O}_{2} / \mathrm{CO}_{2}$ (95.5). Short-circuit current (Isc), which reflects ion transport (mainly $\mathrm{Na}^{+}$and $\mathrm{Cl}^{-}$) across the mucosa (Field et al, 1971), was continuously monitored. Transepithelial potential difference (PD) was measured at regular intervals and tissue conductance was calculated according to Ohms law: $G=$ Isc/PD, where $G$ is an indicator of tight junction leakiness (Madara, 1989). After checking the stability of electrical parameters for $30 \mathrm{~min}, 10 \mathrm{mg}$ of $\beta$-LG trace labeled with ${ }^{14} \mathrm{C} \beta$ LG (final activity $10^{6} \mathrm{cpm} / \mathrm{mg}$ ) were added to the mucosal compartment. Aliquots from both serosal and mucosal reservoirs were collected every
$20 \mathrm{~min}$ for radioactivity measurements. After $2 h$, the entire contents of both reservoirs were collected and subjected to HPLC analysis. Ninety-seven and $98 \%$ of the radioactivity added on the mucosal side of the tissue, was recovered in the same compartment at the end of the experiment for control and lactose-fed rats, respectively.

\section{High performance liquid chromatography}

Five-ml samples were diluted with the same volume of buffer (water $+0.07 \%$ trifluoroacetic acid), and injected into a Waters $c 18$ $\mu$ bondapack column $(3.9 \times 30 \mathrm{~cm})$ with a $0.5 \mathrm{ml} /$ min flow rate. Elution of retained material was achieved with a 2-step (0-35 and 35-67\%) linear gradient of acetonitrile, at a flow rate of $2 \mathrm{ml} /$ min. Two-ml fractions were collected for radioactivity measurements. Standards of radiolabeled $\beta-L G$ were chromatographied in the same way.

\section{Statistical analysis}

Results are expressed as mean $\pm S D$. Linear regression analysis was used to calculate the rate of protein transport. Analysis of variance and Tukey Studentized $t$-test were used to analyze the results.

Table I. Electrical parameters of control and lactose-fed rats' jejunum in the Ussing chamber. Effect of $1 \mathrm{mg} / \mathrm{ml} \beta$-lactoglobulin ( $\beta-L G$ ). Values are means \pm standard errors for $n=5$ tissues and represent the average value recorded during the $2 \mathrm{~h}$ experiments. " significantly different from paired control, $P<0.05$.

\begin{tabular}{lrrrr}
\hline & \multicolumn{2}{c}{ Control rats } & \multicolumn{2}{c}{$\begin{array}{c}\text { Lactose-fed rats } \\
\beta-L G\end{array}$} \\
& Ringer & $\beta-L G$ & Ringer & \\
\hline Isc $\left(\mu \mathrm{A} / \mathrm{cm}^{2}\right)$ & $42.7 \pm 8.1$ & $46.5 \pm 7.3$ & $25.8 \pm 6.3^{*}$ & $24.4 \pm 12.3^{*}$ \\
$\mathrm{PD}(\mathrm{mV})$ & $2.1 \pm 0.5$ & $2.0 \pm 1.0$ & $1.8 \pm 0.3$ & $1.4 \pm 0.7$ \\
$\mathrm{G}\left(\mathrm{mS} / \mathrm{cm}^{2}\right)$ & $20.1 \pm 1.3$ & $23.0 \pm 2.3$ & $14.7 \pm 3.0^{*}$ & $15.5 \pm 2.6^{*}$ \\
\hline
\end{tabular}




\section{RESULTS}

${ }^{14} \mathrm{C} \beta$-LG was added, at a final concentration of $1 \mathrm{mg} / \mathrm{ml}$, on the mucosal side of both the control and lactose-fed rat jejunum mounted in the Ussing chamber (table I). Lactose-fed rat tissue exhibited a significantly reduced Isc and $\mathrm{G}$, compared to control tissue. The mucosal addition of $\beta$-LG did not induce any variation in electrical parameters in either control, or lactosefed, rat jejunum.

After the addition of radiolabeled $\beta$ LG on the mucosal side of the tissue, the radioactivity that appeared on the serosal side of the tissue was measured at regular intervals (fig 1). The amount of radioactivity recovered from the serosal compartment increased as a function of time. After $40 \mathrm{~min}$, this amount was significantly smaller for the jejunum of lactose-fed rats than for controls, and this difference increased as the experiment progressed. At steady state, the rate of absorption of radiolabeled material was significantly reduced $(-58 \%, P<0.05)$ in lactose-fed rats compared to controls $(8.0 \pm 1.7$ and $19.0 \pm$ $2.1 \mu \mathrm{g} \beta-\mathrm{LG} \cdot \mathrm{h}^{-1} \cdot \mathrm{cm}^{-2}$, respectively).

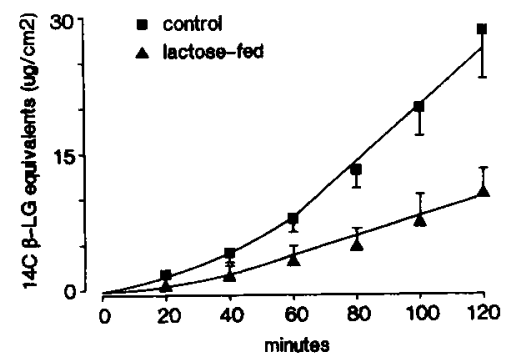

Fig 1. Time dependant accumulation of radiolabeled material in the serosal reservoir of the Ussing chamber for both control and lactose-fed rats. ${ }^{14} \mathrm{C}$ labeled $\beta$-LG was added in the mucosal compartment at $t=0 \mathrm{~min}$. Absorption is linearly related with time after $60 \mathrm{~min}$.

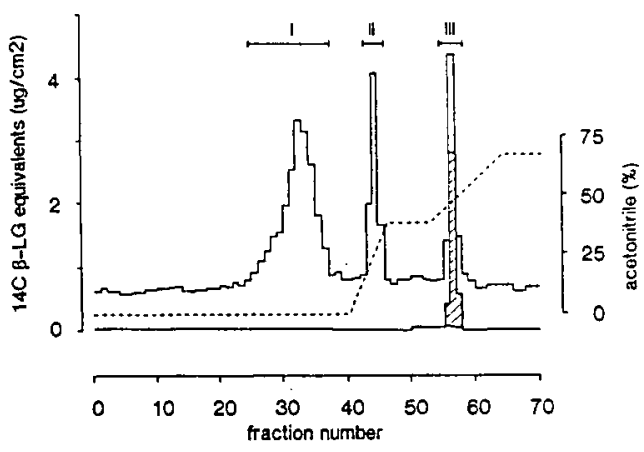

Fig 2. Reverse-phase HPLC analysis of the serosal compartment contents of an Ussing chamber $120 \mathrm{~min}$ after the addition of ${ }^{14} \mathrm{C} \beta-\mathrm{LG}$ to the mucosal compartment. $2 \mathrm{ml}$ fractions were collected. Hatched figure represents elution pattern of the labelled $\beta-L G$ standard. Dotted line represents the $\%$ of acetonitrile present in the elution solvent.

Reverse phase HPLC analysis of the serosal contents, collected after $120 \mathrm{~min}$ of incubation, revealed the existence of 3 main fractions (fig 2). Fraction I represent unretained hydrophilic material and consisted primarily of amino acids and small peptides. Fraction II and fraction III were eluted with $30 \%$ and $46.5 \%$ acetonitrile, respectively. The former, most likely consisted of small peptidic fragments, whereas the latter contained mostly intact $\beta-L G$ and large hydrophobic peptides, as can be assumed by chromatography of $\beta$-LG standards. The relative importance of each of these 3 fractions was similar for both lactose-fed and control rats (table II). Fraction III represented $16 \pm 8$ and $12 \pm 7 \%$ of the radioactive material for control and lactose-fed rats, respectively. For lactosefed rats, the amount of protein recovered in fraction III, and fractions I + II, represent 33 and $41 \%$ of protein recovered from the 
Table II. Amount of radioactive material (in $\mu \mathrm{g}$ equivalents of $\beta$-lactoglobulin) recovered in each fraction after reverse phase HPLC analysis of serosal compartment contents. Results represent means \pm standard errors for $n=5$ experiments. Results are expressed in terms of the total serosal compartment contents $(10 \mathrm{ml}) .90 \%$ of the radioactivity injected in the HPLC was recovered.

\section{Control rats Lactose-fed rats}

\begin{tabular}{lcc} 
Total absorbed & $27.5 \pm 6.6$ & $11.2 \pm 2.4$ \\
Fraction I & $13.8 \pm 3.4$ & $5.6 \pm 2.8$ \\
& $(50 \%)$ & $(50 \%)$ \\
Fraction II & $9.4 \pm 3.0$ & $4.2 \pm 2.0$ \\
& $(34 \%)$ & $(38 \%)$ \\
Fraction III & $4.3 \pm 2.2$ & $1.4 \pm 1.1$ \\
& $(16 \%)$ & $(12 \%)$ \\
\hline
\end{tabular}

controls. Tissue conductance did not correlate with either the quantity of radioactive material present on the serosal side of the jejunum at the end of the experiment, or the amount of radioactivity recovered in fraction III ( $r=0.21$, NS and $r=0.18$, NS, respectively).

\section{DISCUSSION}

This study shows that $\beta$-lactoglobulin is readily absorbed by the small intestine of adult rats, and confirms that part of the absorbed $\beta-L G$ is recovered on the serosal side of the tissue as intact protein or large hydrophobic fragments. It also demonstrates that $\beta$-LG absorption may be reduced by lactose-feeding.

It is well known that protein absorption occurs in the small intestine of adult animals (Cornell et al, 1971; Warshaw et al, 1974; Heyman et al, 1982; Marcon-Genty et al, 1989). In the present study, the rate of $\beta$-LG absorption through rat jejunum in vitro, as determined by transfer of radio- active material, was slightly higher than that previously reported for rabbit ileum (Marcon-Genty et al, 1989). The nature of the absorbed material provides information on the intracellular processing which occurs during protein transport (Walker et al, 1972; Stern and Walker, 1984). Our results indicate that most of the absorbed $\beta-L G$ is recovered as amino acids and small peptides, and that about $12-15 \%$ is transported as intact protein or large hydrophobic peptides. It has been previously reported that $6-9 \%$ of the $\beta-L G$ that is absorbed by rabbit ileum in vitro, is transported as antigenic material (Marcon-Genty et al, 1989).

Lactose-feeding of lactase-deficient animals has been shown to affect different aspects of intestinal function, such as mineral absorption (Armbrecht and Wasserman, 1976; Andrieux et al, 1982; Debiec et al, 1985), steroid absorption (Iritani and Wells, 1966) and epithelial cell turnover (Meslin et al, 1981). In the present study, we observed reduced tissue conductance and short-circuit current, and decreased $\beta$-LG absorption in vitro by lactose-fed rat jeju- 
num, compared to the control. Tissue conductance is known to reflect ion permeation through tight junctions (Madara, 1989), and it has been previously observed that $G$ decreases with cell turnover. Therefore, one could assume that lactose-feeding of adult rats results in reduced leakiness of the intestinal epithelium, and that this is a possible consequence of the previously described slowdown of epithelial cell turn-over (Meslin et al, 1981). The reduction of $\beta$-LG absorption may not result from a change in paracellular transport of proteins since the intact and degraded components of protein transport were decreased to the same extent and no correlation was observed between protein transport and tissue conductance. An alteration of proteolytic activity of epithelial cells also seems unlikely, since the proportion of protein that crossed the mucosa as small peptides or amino acids was the same in control and lactosefed rats. Rather the difference in $\beta-L G$ transport across jejunal mucosa could be a result of decreased protein uptake at the brush-border level. This hypothesis is in agreement with the assumption that protein transport across intestinal mucosa is mainly intracellular and that endocytosis is the main limiting step.

The origin of the modification of $\beta-L G$ uptake by the brush-border membrane of lactose-fed rat intestine remains unclear. Lactase activity of the intestinal mucosa of adult rats is low and lactose is known to be poorly absorbed in the small intestine (Kim et al, 1978). Unhydrolyzed lactose has been shown to enhance phosphate diffusion through direct modification of the intestinal brush-border membrane characteristics of the rat (Debiec and Lorenc, 1985). Such a modification might be responsible for the lactose-induced decrease in $\beta-L G$ absorption. Decreased endocytosis may also result from a slowdown in epithelial cell turnover, previously described (Meslin et al, 1981). In this latter case, the effect of lactose should represent a consequence of its action on gut microflora, since the increase in epithelial cell renewal time has not been observed in germ-free rats (Meslin et al, 1981). In adult rats, lactosefeeding is known to shift the microflora to a fermentative type in the large bowel and to a lesser extent in the small intestine (Adrian and Frangne, 1978; Wise et al, 1984; Morishita and Shiromizu, 1987). However, there is no simple hypothesis to explain how such a shift could result in decreased epithelial turnover.

These results illustrate the impact of particular nutrients on intestinal function. Whatever the mechanism, lactose seems to strengthen the intestinal barrier against luminal macromolecular antigens and might, therefore, contribute to intestinal maturation in the young mammal.

\section{ACKNOWLEDGMENT}

We would like to thank Mrs Laura Winters for assistance in improving the English of this manuscript.

\section{REFERENCES}

Abrams GD, Bauer H, Sprinz H (1963) Influence of the normal flora on mucosal morphology and cellular renewal in the ileum. A comparison of germ free and conventional mice. Lab Invest 12, 355-364

Adrian J, Frangne R (1978) Rôle de la flore digestive dans l'adaptation du rat à une alimentation lactosée. J Internat Vitaminol Nutr 48 , 170-176

Andrieux C, Sacquet E, Guéguen L (1982) Microbial flora in the digestive tract and action of lactose on mineral metabolism. Reprod Nutr Dev 22, 387-394 
Armbrecht $H$, Wasserman RH (1976) Enhancement of $\mathrm{Ca}^{++}$uptake by lactose in the rat small intestine. J Nutr 106, 1265-1271

Cornell R, Walker WA, Isselbacher KJ (1971) Small intestinal absorption of horseraddish peroxydase. A cytochemical study. Lab Invest $25,42-48$

Debiec H, Lorenc R (1985) Effect of lactose on phosphate transport into intestinal brush border membrane vesicles. J Nutr 115, 11681172

Ecknauer R, Sicar B, Johnson LR (1981) Effect of dietary bulk on small intestinal morphology and cell renewal in the rat. Gastroenterology 81. 781-786

Fällstöm SP, Ahlstedt S, Hanson LA (1978) Specific antibodies in infants with gastrointestinal intolerance to cow's milk protein. Inst Archs Allergy Appl Immunol 56, 97-105

Field M, Fromm D, Mc Coll I (1971) lon transport in rabbit ileal mucosa. I. $\mathrm{Na}$ and $\mathrm{Cl}$ fluxes and short-circuit current. Am J Physiol 220, 13881396

Gotteland $M$, Isolauri $E$, Heyman $M$, Tomé $D$, Desjeux JF (1989) Antigen absorption in bacterial diarrhea: in vivo intestinal transport of $\beta$-lactoglobulin in rabbits infected with the entero-adherent Escherichia coli strain RDEC-1. Pediatr Res 26, 237-240

Heyman M, Ducroc R, Desjeux JF, Morgat JL (1982) Horseradish peroxydase transport across adult rabbit jejunum in vitro. $A m J$ Physiol 242, G558-G564

Huang Q, Coleman JW, Stanworth D (1985) investigation of the allergenicity of $\beta$ lactoglobulin and its cleavage fragments. Int Archs Allergy Appl Immunol 78, 337-344

Iritani N, Wells WW (1966) Turnover of cholesterol $-4-{ }^{14} \mathrm{C}$ and cholic acid $-24-{ }^{14} \mathrm{C}$ by rabbits fed a diet containing lactose. $J$ Lipid Res $7,372-378$

Jentoft N, Dearborn DG (1979) Labelling of protein by reductive methylation using sodium cyanoborohydride. J Biol Chem 254, 43594365

Johnson LR (1976) The trophic action of gastrointestinal hormones. Gastroenterology 70 , 278-288
Kim KI, Benevenga NJ, Grummer RH (1978) Estimation of the fraction of the lactose in a high lactose diet available for fermentation in the cecum and colon of the rat. J Nutr 108, 79-89

Koritz TN, Suzuki S, Coombs RRA (1987) Antigenic stimulation with proteins of cow's milk via the oral route in guinea pigs and rats. I. Measurement of antigenically intact $\beta$ lactoglobulin and casein in the gastrointestinal contents of Duodenum jejunum and ileum. Int Archs Allergy Appl Immunol 82, 72-75

Li Y, Tomé D, Desjeux JF (1989) Indirect effect of casein phosphopeptides on calcium absorption in rat ileum in vitro. Reprod Nutr Dev 29, 227-233

Madara JL (1989) Loosening tight junctions. Lessons from the intestine. $J$ Clin Invest 83 , 1089-1094

Marcon-Genty D, Tomé D, Kheroua O, Dumontier AM, Heyman M, Desjeux JF (1989) Transport of $\beta$-lactoglobulin across rabbit ileum in vitro. Am J Physiol 256, G943G948

Meslin JC, Sacquet E, Raibaud P (1974) Effet d'une flore microbienne qui ne déconjugue pas les sels biliaires sur la morphologie et le renouvellement cellulaire de la muqueuse de l'intestin grêle du rat. Ann Biol Anim Bioch Biophys 18, 295-303

Meslin JC, Sacquet E, Riottot M (1981) Effect of various modifications in the diet on ileal epithelium renewal in germ-free and conventional rats. Reprod Nutr Dev 21, 651-659

Miranda G, Pelissier JP (1983) Kinetic studies of in vivo digestion of bovine unheated skimmilk proteins in the rat stomach. $J$ Dairy Res 504, 27-36

Morishita Y, Shiromizu K (1987) Effects of dietary lactose and purified diets on intestinal microflora of rats. Japan J Med Sci Bio/ 40, 1526

Papiz MZ, Sawyer L, Eliopoulos EE, North ACT, Findlay JBC, Sivaprasadarao R, Jones TA, Newcomer ME, Kraulis PJ (1986) The structure of $\beta$-lactoglobulin and its similarity to plasma retinol-binding protein. Nature 324, 383-385

Reddy IM, Kella NKD, Kinsella JE (1988) Structural and conformational basis of the resistance of $\beta$-lactoglobulin to peptic and chymo- 
tryptic digestion. J Agric Food Chem 36, 737-741

Said HM, Ong DE, Shingleton JL (1989) Intestinal uptake of retinol: enhancement by bovine milk $\beta$-lactoglobulin. Am J Clin Nutr 49, 690694

Stern M, Walker WA (1984) Food proteins and gut mucosal barrier. I. Binding and uptake of cow's milk proteins by adult rat jejunum in vitro. Am J Physiol 246, G556-G562

Udall JN, Walker WA (1982) The physiologic and pathologic basis for the transport of macromolecules across the intestinal tract. $J P_{e}$ diatr Gastroenterol Nutr 1, 295-301
Walker WA, Cornell R, Davenport IM, Isselbacher KJ (1972) Macromolecular absorption: mechanism of horseradish peroxydase uptake and transport in adult and neonatal rat intestine. $J$ Cell Biol 54, 195-205

Warshaw AL, Walker WA, Isselbacher KJ (1974) Protein uptake by the intestine: Evidence for the absorption of intact macromolecules. Gastroenterology 66, 987-992

Wise A, Rowland IR, Mallet AK (1984) Dietary lactose and the metabolic activity of the caecal microfloras of weanling and adult rats. $F d$ Chem Toxic 22, 113-117 